\title{
Safety, Efficacy and Acute Angiographic Outcome of the New Everolimus Eluting Stent with Correlation to Short-Term Clinical Follow-up in Patient with Acute Coronary Syndrome
}

\author{
MOHAMED IMAM, M.D.**; SOLIMAN GHARIB, M.D.*; MOHAMED ABDELGHANY, M.D.* and \\ HOSSAM ELHOSSARY, M.D.* \\ The Department of Cardiology, Faculty of Medicine, Cairo University* and National Heart Institute (NHI) **, Giza, Egypt
}

\begin{abstract}
Background: Drug-eluting stents are used in $80 \%$. To $90 \%$ of revascularization procedures in the United States. Everolimus embedded in a durable polymer on a cobalt chromium Stent has shown superiority compared with Bare Metal Stents (BMS), and paclitaxel eluting stent for reduction of both late loss and binary restenosis.

Aim of Study: To study the safety, efficacy and acute angiographic outcome of the new Everolimus Eluting Stent in correlation with short-term clinical follow-up in patient with Acute Coronary Syndrome (ACS).

Patients and Methods: A prospective study in which ninety-five patients with (ACS), Scheduled for PCI in the cardiac catheterization laboratory in Cairo University Hospitals or NHI, using Everolimus DES, were enrolled from Jan. 2009 to June 2009. Their clinical, angiographic, interventional and follow-up data were collected and analyzed.

Results: Acute success was achieved in all the cases with no device failure, after six month of follow-up, patients (94.5\%) had expressed no events or chest pain, 1 patient had stable angina and refused to redo the coronary angiography, 3 patients had redo the coronary angiography due to recurrent chest pain (two of them had redo PCI in remote vessel and the other had no significant lesion), and 1 patient died because of retroperitoneal hematoma.
\end{abstract}

Conclusion: The everolimus eluting stent are a safe type of drug eluting stent in clinical Practice with favorable short term outcomes in patients with acute coronary syndromes.

Key Words: Everolimus eluting stent - Acute coronary syndrome.

\section{Introduction}

DRUG-ELUTING stents were used in $80 \%$ to $90 \%$ of revascularization procedures In the United

Correspondence to: Dr. Mohamed Imam, The Department of Cardiology, Faculty of Medicine, Cairo University, Giza, Egypt
States in 2005 however, reports of an increased incidence of late stent thrombosis, defined as thrombosis occurring more than 10 days after implantation have raised concerns about a safety tradeoff with this technology.

Everolimus is a derivative of the liums family. A sirolimus analogue with a single minimal alteration in its molecular structure (Position 40). Without a chemical modification of the mTOR binding domain $[\mathbf{1 , 2}]$. Of interest is that when implanted in rabbit iliac arteries. Amore rapid endothelialization of the struts with exhibition of ed31 (antigen surface marker of good endothelial functionality) in the cells as 14 days (R.Virmani, MD, unpublished data, 2006).

Everolimus is agent that is used in heart transplantation as it has been shown to reduce chronic -allograft vasulopathy in such transplants. It may also have similar role to sirolimus in kidney and other transplants [3].

The clinical evaluation of the Everolimus Eluting Coronary Stent System in the Treatment of Patients with de novo Native Coronary Artery Lesions First (SPIRIT) trial proved the superiority of Everolimus embedded in a durable polymer on a cobalt chromium stent as compared with Bare Metal Stents (BMS) [4,5]. In the recently completed SPIRIT-II trial, proved to be superior to the Paclitaxel Eluting Stent for reduction of both late loss and binary restenosis [6]. Subsequently, the SPIRITIII trial has randomized 1002 patients in the US to treatment with either an Everolimus Eluting Stent or a Paclitaxel Eluting Stent. As part of the SPIRIT-III study, additional patients will also be enrolled in 4 registry arms in Japan. 
Aim of the work:

To study the safety, efficacy and acute angiographic outcome of the new Everolimus Eluting Stent with correlation to short-term clinical followup in patient with Acute Coronary Syndrome.

\section{Patients and Methods}

\section{I- Patients selection:}

It is a prospective study in which all patients with Acute Coronary Syndromes who were scheduled for Percutaneous Coronary Intervention in the cardiac catheterization laboratory in Cairo University Hospitals or National Heart Institute using Everolimus DES were enrolled in this study from Jan. 2009 to June 2009.

\section{II- Clinical and laboratory data:}

Full clinical data including medical history and clinical examination was obtained from the patients with special emphasis on:

\section{A- Risk factors for coronary artery disease:}

1- Age and gender.

2- The major documented risk factors for CAD: Smoking, diabetes, hypertension, dyslipidemia and positive family history for premature CAD.

- Diabetes mellitus: Was diagnosed by a fasting blood glucose level of $\geq 126 \mathrm{mg} / \mathrm{dl}$ on two occasions according to American Diabetes Association or history of taking insulin or oral hypoglycemic [7]

- Systemic arterial hypertension: Was diagnosed by persistent blood pressure readings of $>140 / 90$ according to (JNC VII), or history of taking antihypertensive treatment [8] .

- Hypercholesterolemia: Was diagnosed by a total cholesterol level of $>200 \mathrm{mg} / \mathrm{dl}, \mathrm{LDL} \geq 100 \mathrm{mg} /$ $\mathrm{dl}$ and $\mathrm{HDL}<40 \mathrm{mg} / \mathrm{dl}[9]$.

- Positive family history of CAD or sudden cardiac death was defined as coronary artery disease in first degree male relative before age of 55 years and in first degree female relative before age of 65 years [10].

\section{B- Clinical presentation:}

The patient was categorized under the following:

1- Unstable angina, according to Braunwald classification of unstable angina [1]

2- Myocardial infarction: Defined according to the Consensus Document of the Joint European Society of Cardiology/American Colleague of Cardiology Committee for the Redefinition of Myocardial Infarction [12].
I- Acute, evolving MI: Typical rise and gradual fall of cardiac enzymes (CK, CK-MB and Troponin) with at least one of the following:

1- Ischemic symptoms.

2- Development of pathological Q waves on the ECG.

3- ECG changes indicative of ischemia (ST segment elevation or depression).

4- Coronary artery intervention (e.g., coronary angioplasty).

II- Established recent MI: Development of new pathological Q waves on serial ECG, the patient may or may not remember previous symptoms, biochemical markers of myocardial necrosis may have normalized, depending on the length of time that has passed since infarct developed [12]

C- Twelve lead Electrocardiogram (ECG): On admission, immediately after the procedure and 24 hours later was obtained.

III- Preprocedural management: Antiplatelet therapy was used routinely including aspirin $150 \mathrm{mg}$ daily plus clopidogrel $300 \mathrm{mg}$ loading dose unless pretreatment for several days had been performed; it was loaded by $600 \mathrm{mg}$ in acute situation, Glycoprotein IIb/IIIa receptor antagonist was used when there is an expected increased risk of abrupt closure or distal embolization.

IV- Angiographic data: Angiographic analysis was performed immediately before intervention, after Percutaneous Trans luminal coronary angioplasty and finally after stenting procedure.

For proper analysis and measurement, the following steps were followed:

I- Angiographic analysis will be done in end diastolic cine frames in identical projections using the contrast filled guiding catheter as a scaling device for calibration.

II- Angiographic analysis and measurements will be performed in two orthogonal angiographic projections and if orthogonal projection is not available as in case of branch overlapping, analysis will be done using the projection showing the worst results [17].

\section{A- Syntax score:}

Syntax score was calculated for patients' coronary angiography studies.

\section{The SYNTAX score algorithm:}

The SYNTAX score [14] is calculated by a computer program consisting of sequential and interactive self-guided questions. 


\section{$\mathrm{V}$ - Interventional data:}

The following data were obtained:

1- Wire: Types and number of wires.

2- Balloon: Type, size, number of inflation, maximum inflation pressure of the balloon.

3- Stent: Size, deployment pressure and maximum dilation pressure.

\section{VI- Procedural outcome:}

\section{I- Acute angiographic outcome:}

A- Angiographic success: Defined as restoration of antegrade TMIMI III wih no residual stenosis [13].

\section{B- Adverse angiographic outcome:}

I- Abrupt vessel closure: Defined as obstruction of contrast flow (TIMI 0-1) in a dilated Segment with previously documented ante grade flow (post interventional) [14].

2- Coronary artery dissections: Classified according to National Heart Lung Blood Institute (NHLBI) criteria [15]:

- Type A: Small radiolucent area within the lumen of the vessel.

- Type B: Linear non-persisting extravasation of contrast.

- Type C: Extra luminal persistent extravasation of contrast.

- Type D: Spiral shaped filling defect.

- Type E: Persistent lumen defect with delayed ante grade flow.

- Type F: Filling defect accompanied by total coronary occlusion.

3-No-reflow phenomenon: Acute reduction in ante grade flow (TIMI 0-1), not attributable to abrupt closure, severe dissection of the original target lesion or to epicedial coronary spasm [13].

4- Side branch loss (jailing): TIMI <2 flow in side branch $>1.5 \mathrm{~mm}$ in diameter that previously had TIMI grade 3.

5- Coronary artery perforation:Classified according to the classification scheme of Coronary perforation proposed by Ellis et al. [16].

- Type I: Extra luminal crater without extravasation.

- Type II: Pericardial or myocardial blush without contrast jet extravasation.

- Type III: Extravasation through frank (> $1 \mathrm{~mm}$ ) perforation.
6- Stent thrombosis [17].

A- Acute: Angiographically documented occlusion with TIMI flow grade 0 or 1 at the stent site occurring within 24 hours of the stent procedure.

B-Subacute: From $24 \mathrm{~h}$ to 1 month.

\section{II- Clinical outcome:}

It is defined as angiographic success not associated with a major in hospital.

Complication (death, myocardial infarction, emergency CABG surgery or Re-PTCA, arrhythmia as VT or Acute pulmonary edema.

\section{VII- Post-procedural-management:}

When the operator was confident that the best possible result had been obtained, the patient was returned to his/her room where a 12-lead ECG was obtained, and the arterial sheath was removed at 2-4 hours after the procedure if a PTT is below 45 seconds and mobilization will be delayed for 1224 hours, and then discharged 1-3 days following the procedure and instructed to use the clopidogrel $75 \mathrm{mg}$ daily for one year at least.

\section{VIII- Clinical follow-up data:}

All patients with successful PCI were followedup clinically for 6 months; the following end point will be traced and documented:

1- Recurrent attacks of angina.

2- Unstable angina.

3- Acute Myocardial infarction [ST elevation myocardial infarction (STEMI) or Non-ST elevation myocardial infarction (NSTEMI)]: Defined according to third definition of myocardial infarction [18].

4- Emergency in hospital coronary artery bypasses grafting or repeat PTCA + stenting.

5- Heart failure.

6- Sudden cardiac death.

7- Only symptomatic patient will be subjected coronary angiography and restenosis will be defined as diameter stenosis $>50 \%$ at followup CA [19].

\section{Results}

The study included 95 patients (all comers) diagnosed as having acute coronary syndrome admitted to the National Heart Institute, Coronary Care Units (CCU) and Cairo University Hospital CCUs over the period from January 2009 to January 2010 and were in need for percutaneous coronary intervention. 


\section{A- Patient demographic data:}

Diagnosis: As shown in Fig. (1):

For all our patients, the initial diagnosis based on the initial ECG pattern was either: Acute coronary syndrome with ST elevation, acute coronary syndrome with ST depression and/or inverted T wave, and acute coronary syndrome with nonspecific ECG changes.

Most of our patients 75 (78.9\%) had an initial diagnosis of unstable angina, 15 patients representing (15.8\%) were initially diagnosed as ACS with ST elevation myocardial infarction, while NSTEMI in 5 patients $(5.3 \%)$ only.

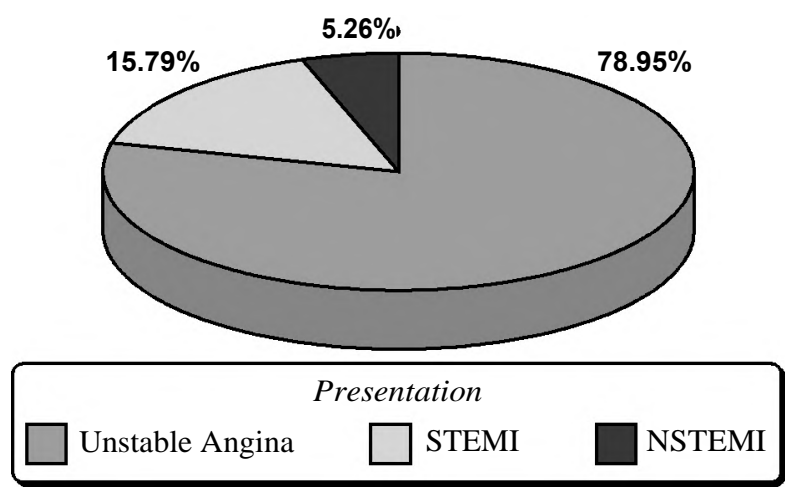

Fig. (1): Initial diagnosis of ACS.

Sex:

Most of our study populations were males 79 (83.2\%), and females were only $16(16.8 \%)$.

Age:

The age of our patients ranged from 31 to 80 , with a mean \pm SD $59.58 \pm 9.97$ years.

\section{Risk factors:}

Diabetes was the most significant risk factor among our patients. Diabetics represented $67 \%$ of the whole studied group. Also, dyslipidemia was found to be a significant risk factors as it was prominent in $62(65 \%)$ of all studied group.

Hypertension showed in 56 patients $(59 \%)$ with non-significant $p$-value $(0.1)$.

Renal impairment was found in 17 patients (17.7\%), 14 patient (14.7\%) of them had serum Creatinine $(1.5-3 \mathrm{mg} / \mathrm{l})$ and the remaining 3 patients $(3.2 \%)$ were having creatinine more than $3 \mathrm{mg} /$.

\section{B- Angiographic data:}

Sixty two patient's $(65.3 \%)$ had simple lesion while 26 patients $(27.4 \%)$ had two lesions, 5 patients $(5.3 \%)$ had three lesions and 2 patients (2.1\%) had 4 lesions, [mean \pm SD $1.44 \pm 0.69$ lesion] (Table 1).

\section{Coronary angiography findings:}

Table (1): Number of each coronary artery segment affected during coronary angiography.

\begin{tabular}{lcc}
\hline Segment & Number & Percent \\
\hline LAD proximal & 28 & 20.6 \\
LAD mid & 28 & 20.6 \\
RCA mid & 17 & 12.5 \\
LCX mid & 11 & 8.1 \\
OM 1 & 9 & 6.6 \\
RCA proximal & 9 & 6.6 \\
RCA distal & 8 & 5.9 \\
LCX proximal & 6 & 4.4 \\
PDA & 5 & 3.7 \\
D1 & 4 & 2.9 \\
LM & 4 & 2.9 \\
Venous graft & 2 & 1.5 \\
Internal mammary artery & 2 & 1.5 \\
OM2 & 1 & .7 \\
PLA & 1 & .7 \\
D2 & 1 & .7 \\
\hline Total & 136 & 100.0 \\
\hline
\end{tabular}

Abbreviations:

LAD : Left Anterior Descending Artery, left circumflex artery.

OM : Obtuse Marginal.

RCA : Right Coronary Artery.

PDA : Posterior Descending Artery.

D1 : First Diagonal.

LM : Left Main.

PLA : Posterior-Lateral Artery.

D2 : Second Diagonal.

\section{Intervention data:}

Balloon:

In 69 lesion $(50.7 \%)$ of the lesions the direct stent technique was used, while in 67 lesion $(49.3 \%)$ the pre-balloon dilatation was used.

Stents:

Table (2): Summonses the types of stents used when $89 \%$ of them used XIENCE.

\begin{tabular}{lcl}
\hline Stent & Frequency & Percent \\
\hline XIENCE & 121 & 89.0 \\
Cypher & 8 & 5.9 \\
Taxus & 4 & 2.9 \\
Endeavour & 1 & .7 \\
Driver & 1 & .7 \\
Vision & 1 & .7 \\
\hline Total & 136 & 100.0 \\
\hline
\end{tabular}

Syntax score:

The Syntax score was calculated for 91 patients, with a minimum Syntax score of 2 and maximum of 29.5 and mean $9.7 \pm 6.2$.

\section{Syntax score category:}

As shown in (Table 3 ) the Syntax score category was in the mild zone (from 0-22) 85 patients 
$(89.5 \%)$ of the patients, and was in the moderate zone (from 23-32) in 6 patients $(6.3 \%)$ of the patients, while 4 patients (4.2\%) were post CABG.

Table (3): Syntax score category.

\begin{tabular}{lcc}
\hline Category & Frequency & Percent \\
\hline Mild & 85 & 89.5 \\
Moderate & 6 & 6.3 \\
Grafts & 4 & 4.2 \\
\hline Total & 95 & 100.0 \\
\hline & & \\
\hline
\end{tabular}

Fig. (2): Syntax score category.

D- Follow-up data:

Table (4): Follow-up data.

\begin{tabular}{lcc}
\hline & Frequency & Percent \\
\hline No event & 90 & 94.6 \\
Stable angina & 1 & 1.1 \\
Re angio & 3 & 3.3 \\
Non cardiac death & 1 & 1.1 \\
\hline Total & 95 & 100.0 \\
\hline
\end{tabular}

\section{Discussion}

In our study, mean \pm SD age of the patients was $59.58 \pm 9.97$ years, the majority of the population were males $79(83.20 \%)$ with 16 females $(16.80 \%)$. The most prevalent coronary risk factor was diabetes mellitus (67\%), followed by dyslipidemia (65\%), smoking (65\%) and hypertension (59\%). Renal impairment was found in 17 patients (17.7\%). Most of our patients 75 (78.9\%) had an initial diagnosis of unstable angina, 15 patients (15.8\%) were initially diagnosed as ACS with ST elevation myocardial infarction, while NSTEMI in 5 patients $(5.3 \%)$ only. Most of our patients have native vessels affected (97.8\%) distributed as follows: LM in about $2.9 \%$, LAD in about $41.2 \%$, diagonals in about (3.6\%), RCA (25\%), LCX in about (19.8\%), PDA in about $3.7 \%$, PL in $0.7 \%$ and Grafts in $3 \%$.
Similar to our population profile, was a previous study done Robert et al., [20] mean age of the patients was $63 \pm 12$ years; the majority of the population was males $(65 \%)$. The most prevalent coronary risk factor was hypertension $(78 \%)$, dyslipidaemia (66\%), and smoking $34 \%$, diabetes mellitus $32 \%$, their patients (32\%) had an initial diagnosis of unstable angina, patients representing $(41 \%)$ were initially diagnosed as ACS with ST elevation myocardial infarction, while NSTEMI in (23\%). Most of these patients had native vessels affected $(95 \%)$ distributed as follows: LAD in about $46 \%$, RCA (41\%), LCX in about (31\%), and grafts in $6 \%$.

As you see in our study patient population were younger than done by Robert colleague [20] and this may be due to the increased percentage of the coronary artery disease.

As for risk factors, diabetes was the most important risk factor in our population, this is because the resources are limited in Egypt so the DES are reserved for the high risk patients for restenosis especially the diabetic category.

In our study the smoker were $65 \%$ of the population double in the incidence of smoking in the concordant study and this may explain the increased incidence of the coronary artery disease in the young and males, dyslipidemia was the same incidence in both studies; the hypertension was slightly increased in the concordant study due to the increase of the mean age in their study.

In relation to the initial presentation diagnosis, in our study the percentage of the STEMI patients was much less in our study because of financial aspects some patients preferred to postpone the PCI procedure rather than doing PCI in the acute situation.

No cases of instent thrombosis was detected in our study while it occurred in $1.7 \%$ of patients with in the Robert et al. [20], this may be due to the more usage of Paclitaxel eluting stent that was discovered later on that it was associated with increased risk of stent thrombosis.

In another study Gyöngyösi, et al. [21] has studied the all comer using DES (Taxus stent) for two years follow-up (AUTAX study).

The syntax score were calculated in our study with minimum syntax score of 2 and maximum of 29.5 and a mean $9.7 \pm 6.2$, while in the AUTAX [22] study the score mean 23 ranging from 19.0 to 29.0 [22]. 
Most of the patients had single lesion treated 62 patients $(65.3 \%)$, while 26 patients $(27.4 \%)$ were having two lesions, 5 patients $(5.3 \%)$ were having three lesions and 2 patients $(2.1 \%)$ were having 4 lesions, with mean number of lesions treated per patient $1.44 \pm 0.69$ while in the AUTAX study the mean number of lesions treated per patient was $2.45 \pm 0.31$.

In our study the acute success was achieved in all the cases with no device failure, after six month the clinical follow-up was performed that revealed 90 patients $(94.5 \%)$ had expressed no events or chest pain, while 1 patient had stable angina and was refusing to redo the coronary angiography, 3 patients had redo the coronary angiography due to recurrent chest pain (two of them had redo PCI in remote vessel and the other had no significant lesion), 1 patient died because of retroperitoneal hematoma.

The coronary angiography that was done revealed no significant lesion in two cases and in the third patient who had stopped the clopidogrel after three days of PCI there was remote lesion in another vessel.

Applegate, et al., [20] results at 2 years was the hazard ratio for DES compared with BMS for nonfatal MI or death was 0.77 (95\% Confidence Interval [CI] 0.62 to 0.95 ), for all-cause mortality 0.71 (0.54 to 0.92), and Stent Thrombosis (ST) 0.97 (0.49 to 1.91). "On-label" stent procedures were associated with lower risk of MI, death, and ST than "off-label" stent procedures. For "offlabel" stent procedures, the hazard ratio for DES compared with BMS for nonfatal MI or death was 0.78 (95\% CI 0.62 to 0.98$)$, all-cause mortality 0.72 (0.54 to 0.94 ), and ST 0.91 (0.46 to 1.80 ). The hazard of nonfatal MI or death was similar or lower for DES than BMS in high-risk subgroups, including renal failure and recent MI.

In the AUTAX study [22], complete revascularization was successful in $90.5 \%$, with left main PCI of $6.8 \%$. Rates of acute, sub acute, and late stent thrombosis were $0.7 \%, 0.5 \%$, and $0.5 \%$. Twoyear follow-up identified AMI (1.4\%), death (3.6\%), stroke $(0.2 \%)$, and TLR $(13.1 \%)$, for a composite MACCE of $18.3 \%$. The binary restenosis rate was $10.8 \%$. The median of cumulative SYNTAX score was 23.0 (range 12.0 to 56.5 ). The SYNTAX score did not predict TLR or MACCE, due to lack of scoring of restenotic or bypass stenosis (29.8\%). Age (Hazard Ratio [HR]: 1.03, p 0.019) and acute coronary syndrome (HR: 2.1, p_0.001) were significant predictors of 2-year
MACCE. Incomplete revascularization predicted death or AMI (HR: 3.84, $p$ 0.002).

Our results was much better than the results of the other study, these difference is due to the difference in complexity the mean of their syntax score was 23 while in our study one patient only in the 95 patient was exceeding 23 and the mean of the score was 13 .

Another important issue is that the stent used in their study was the Taxus study that was proved from the spirit trial that it cause more event of in stent thrombosis.

Another important factor is the period of followup, may be if we had extended the period of followup the events will occur.

\section{Conclusion and Recommendation:}

- The Everolimus eluting stent are safe type of stents in clinical practice with favorable short term outcomes in patients with acute coronary syndromes.

\section{References}

1- STONE G.W., ELLIS S.G., CANNON L., MANN J.T., GREENBERG J.D., SPRIGGS D., et al.: TAXUS V Investigators. Comparison of a polymer-based paclitaxeleluting stent with a bare metal stent in patients with complex coronary artery disease: A randomized controlled trial. JAMA, 294: 1215-23. [PMID: 16160130], 2005.

2- SCHULER W., SEDRANI R., COTTENS S., HABERLIN B., SCHULZ M., SCHUURMAN H.J., ZENKE G., ZERWES H.G. and SCHREIER M.H.: SDZ RAD, a new rapamycin derivative: Pharmacological properties in vitro and in vivo. Transplantation, 64: 36-42, 1997.

3- EISEN H.J., TUZCU E.M., DORENT R., et al.: Everolimus for the Prevention of Allograft Rejection and Vasculopathy in Cardiac-Transplant Recipients. New England Joumal of Medicine, 349: 847-58, 2003.

4- SCRRUYS P., AT O., PIEK J.J., NEUMANN F.J., VAN DER GIESSEN W., WIEMER M., ZEIHER A.M., GRUBE E., HAASE J., THUESEN L., HAMM C.W. and OTTOTERLOUW P.: A randomized comparison of a durable polymer Everolimus-eluting stent with a bare metal coronary stent: The SPIRIT first trial. Euro Intervention, 1: 58-65, 2005.

5- TSUCHIDA K., PICK J.J., NEUMANN F.J., VAN DER GIESSEN W., WIEMER M., ZEIHER A.M., GRUBE E., HAASE J., THUESEN L., HAMM C., VELDHOF S., DORANGE C. and SERRUYS P.W.: One-year results of a durable polymer everolimus-eluting stent in de novo coronary nanoowings (The SPIRIT FIRST Trial). Euro Intervention, 1: 266-72, 2005.

6- SERRUYS P.W., RUYGROK P.J.N., PIEK J.J., SETH A., SCHOFER J., RICHARDT G., WIEMER M., CARRIE D., THUESEN L., BOONE E., MIGUEL-HERBERT K. and DAEMCN J.: A randomized comparison of an everolimus eluting coronary stent with a paclitaxel eluting 
coronary stent: The SPIRIT II trial Euro Intervention, 2: 286-94, 2006.

7- GARBER A.J.: Diabetes Mellitus. Textbook of internal medicine. St. Louis, Missouri: MOSBY Company, 185074, 1998.

8- The Seventh Report of The Joint National Committee on Prevention, Detection, Evaluation, and Treatment of high Blood Pressure. Arch. Intern. Med., 157: 2413-46, 1997.

9- GRUNDY S.M.: Small LDL, atherogenic dyslipidemia, and the metabolic syndrome. Circulation, 95: 1-4, 1997.

10-American Heart Association Grading Committee. Coronary Artery Disease Reporting System. Circulation, 51: 31-3, 1975.

11- BRAUNWALD E.: Unstable angina. A. Classification. Circ., 80: 410-14, 1989.

12- ALPERT J.S., THYGESEN K., et al.: Myocardial Infarction Redefined according sto the Consensus Document of the Joint European Society of Cardiology/American Colleague of Cardiology Committee for the Redefinition of Myocardial Infarction J.

13- BELL M.R., BERGER P.B., MENKE K.K. and HOLMES D.R.: Balloon angioplasty of chronic total coronary artery occlusions: What does the cost in radiation Exposure, time, and materials Cathet Cardiovasc Diagi., 25: 10-5, 1992.

14- ABBO K.M., BOONS M., GLAIZER S., et al.: Features and outcome of no-reflow after PCI. Am. J. Cardiol., 75o. 778-82, 1995.

15- JASON H. ROGERS and JOHN M. LASALA: Coronary artery dissection and perforation complicating percutaneous coronary intervention. Invasive Cardiol., 16 (9): 4939, 2004.

16- ELLIS S.G., VANDORMAEL M.G., COWLEY M.J., et al.: Coronary morphologic and clinical determinants of procedural outcome with angioplasty for multivessel coronary disease. Implications for patient selection. Multivessel Angioplasty Prognosis Study Group. Circulation 1990; Am. coli. Cardiol., 959-69, 2000.

17- ARNOUD W.J., HARRY SURYAPRANATA, et al.: Angiographic Assessment of Myocardial Reperfusion in patients Treated With primary Angioplasty for Acute MI Circ., 97: 2302-6, 1988.

18- KRISTIAN THYGCSEN, JOSEPH S., ALPERT, ALLAN S. JAFFE, et al.: ESC/ACCF/AHA/WIIF Expert consensus Document. Third Universal Definition Of Myocardia1 Infarcation. Circulation October, 126-16, 2012.

19- BERGER P.B., HOLMES D.R., OHMAN M., et al.: Restenosis, reclusions and adverse cardiovascular events after successful balloon angioplasty of occluded versus no occluded coronary arteries Jam. Coll. Cardio., 27: 17, 1996.

20- ROBERT J. APPLEGATE, MATTHEW T. SACRINTY, MICHAEL A. KUTCHER, RENATO M. SANTOS, SAN JAY K. GANDHI, TALAL T. BALD and WILLIAM C. LITTLE "Off-Label" Stent Therapy: 2-Year Comparison of Drug-Eluting Versus Bare-Metal Stents J. Am. Coil. Cardiol., 51; 607-14 doi: 10. 10 16/j.jacc.2007.08.064, 2008.

21- GYÖNGYÖSI M.D., GÜNTER CHRIST and IRENE LANG: the 2-Year Results of the AUTAX (Austrian Multivessel TAXUS-Stent) Registry beyond the SYNTAX (Synergy between Percutaneous Coronary Intervention with TAXUS and Cardiac Surgery) study J. Am. Coli. Cardiol. Intv., 2: 718-27, doi: 10.1016/j.jcin. 2009.05.019, 2009.

22- SIANOS G., MOREL M.A., KAPPETEIN A.P., et al.: The SYNTAX score: An angiographic Tool grading the complexity coronary artery disease. Euro intervention, 1: 219-27, 2005 


\section{متابعة إكلينيكية قصيرة المدى اللدعامة الدوائية بالافيروليمس إنيس فى مرضى قصور الشرايين التاجية المئية الحادة}

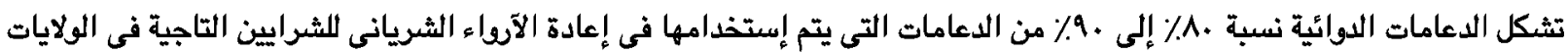

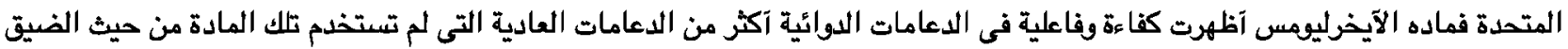

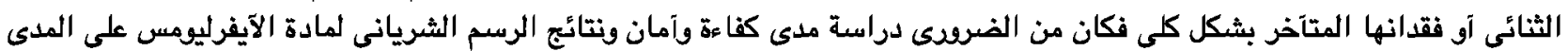

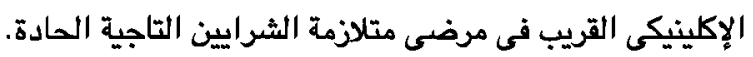

تم عمل الدراسة على ه9 مريض بمتلازمة الشرايين التاجية الصادة الذين تم ترتيب علاج تداخل بالقسطرة للثرايين التاجية لهم، وقد تم

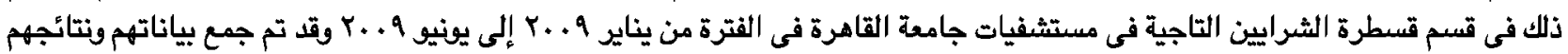
التداخلية وتحليله.

آما عن المرضى محل الدراسة فقد تم آخذ تاريخ مرضى كامل لهم وفحصهم إكلينيكياً بدقة.

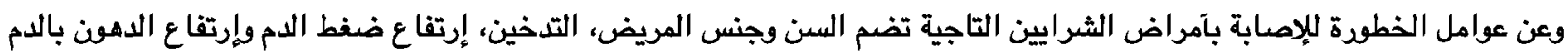

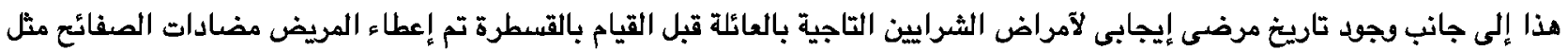
الآسبرين ومادة الكويبدوجريل.

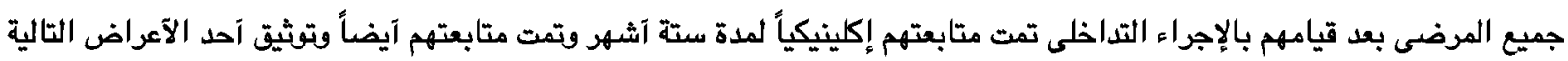

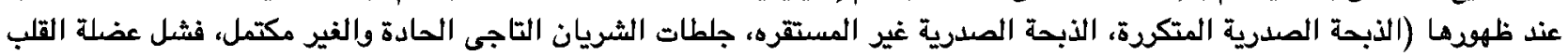
والتوقف المفاجئ فى عضلة القلب.

آغلب المرضى بنسبة تقترب من V9٪ (V0 مريض) تم تشخيصهم بذبحة صدرية غير مستقره، 10 مريض شخصوا بجلطة حادة بالشرايين

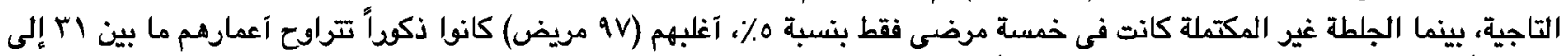

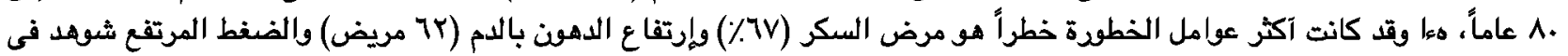

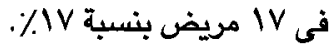

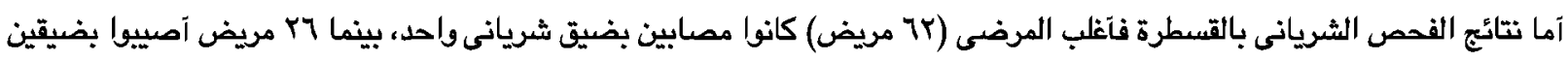

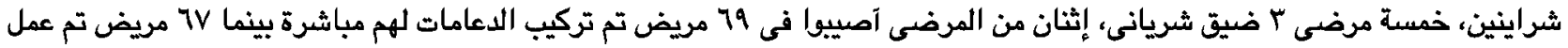
توسيع بالبالون قبل تركيب الدعامة.

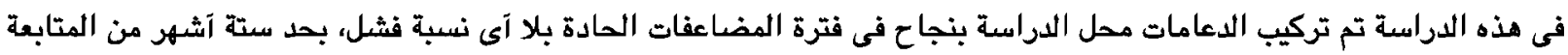

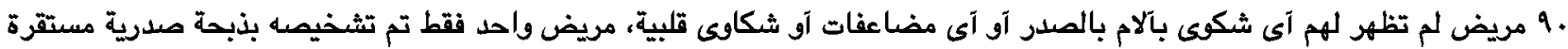

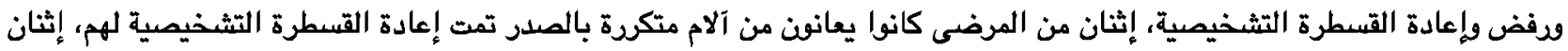

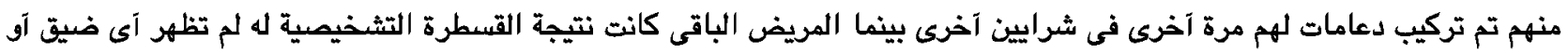
تآثيرات جديدة بالشريان. مريض واحد فقط توفى بسبب تجمع دموى شديد في المكان خلف الفشاء البريتونى. مما سبق نستخلص آن الدعامات المصنعة بالدواء من النوع ايفرليومس هو آكثر الآنواع آماناً فى الممارسات الإكلينيكية بنتائج جيدة على المدى القريب في مرضى متلازمة الشرايين التاجية الحادة. 